\title{
İlköğretim Öğrencilerinin Zorbalığa Maruz Kalma Türünün ve Sıkığının Depresyon, Kaygı ve Benlik Saygısıyla İlişkisi
}

\author{
Emine Gül KAPCI*
}

ÖZ: Bu çalışmanın amacı, a) ilköğretim 4. ve 5. sınıf öğrencilerinin maruz kaldıkları zorbalık türleri, bunların görülme sıklığı, b) zorbalığın görülme türünde sosyo-ekonomik düzey, sınıf düzeyi ve cinsiyete bağlı farklılıkların olup olmadığı ve son olarak c) zorbalığa maruz kalıp kalmamanın benlik saygısı, depresyon, durumluk ve sürekli kaygı düzeylerinde nasıl bir farklılaşmaya neden olduğunu araştırmaktır. Araştırmaya $99 \mathrm{kız}$ ve 107 erkek olmak üzere toplam 206 öğrenci katılmıştır (Yaş X=10.8, SS=.62). Analizler, öğrencilerin $\% 40$ oranında bedensel, sözel, duygusal ve cinsel zorbalığa maruz kaldıklarını, zorbalığın demografik değişkenlerden çok psikolojik değişkenlerle bağlantılı olduğunu göstermiştir. Bulgular zorbalığın eğitim ortamında gösterilmesi bağlamında tartışılmıştır.

Anahtar Sözcükler: Zorbalık, öğrenci, depresyon, benlik saygısı, kaygı, zorbalık türleri

\section{Bullying type and severity among elementary school students and its relationship with depression, anxiety and self esteem}

\begin{abstract}
The purpose of this study is to find out a) types and prevalence rates of bullying experienced by the 4 th and 5th grade children, b) sosyo-economic status, grade and gender differences on the level and type of bullying and finally c) how the self-esteem, depression, state and trait anxiety levels of these pupils differed by the experience/type of bullying. Of the 206 children 99 were girls and 107 were boys with a mean age of 10.8 $(\mathrm{SD}=.62)$. The results demonstrated that $40 \%$ of children have been exposed to physical, verbal, emotional and sexual bullying. Bullying is also found to be more related to psychological variables, rather than demographic ones.
\end{abstract}

Key Words: Bullying, pupil, depression, self-esteem, anxiety, types of bullying.

\section{GİRIŞ}

Akranları ya da arkadaşları tarafından fiziksel, sözel, cinsel ya da duygusal zorbalığa maruz kalan çocukların hem kısa, hem de uzun dönemde bu tür yaşantıdan/yaşantılardan olumsuz biçimde etkilendiğine ilişkin araştırma bulguları giderek artmaktadır (Neary ve Joseph, 1994). Bu alandaki kimi çalışmalar akran istismarı (peer abuse), kimi çalışmalar da zorbalık (bullying) olarak bilinmektedir (Schafer, Werner ve Crick, 2002). İstismarı/zorbalığı yapan kişiye genellikle zorba (bully), maruz kalan kişiye de kurban (victim) denmektedir. Bir başka grup çocuk ise kimi zaman zorba davranışlar sergilemekte, kimi zaman ise zorbalığa maruz kalabilmektedir (Seals ve Young, 2003).

Pişkin (2002), zorbalıkla ilgili bir derleme çalışmasında, zorbalığın çeşitli tanımlarını vermekte ve bu tanımlarda bulunan ortak noktaların altını çizmektedir. Bunlar a) Zorbalık, bilinçli ve kasıtlı olarak yapılan ve kurbana fiziksel, zihinsel, sosyal ya da

\footnotetext{
*Yard. Doç. Dr., Ankara Üniversitesi, Eğitim Bilimleri Fakültesi, İlköğretim Bölümü, kapci@education.ankara.edu.tr
} 
psikolojik zarar verme amacı güden söz ve eylemleri içerir, b) Zorbalığın belli bir süre tekrarlanma özelliği vardır, c) Kurban kendini koruyamayacak ve savunamayacak durumdadır, ç) Zorbalar eylemlerini bireysel ya da grupla yapabildikleri gibi, kurbanlar da bu eylemlerden bireysel ya da grup olarak zarar görebilirler, d) Zorbalar, bu tür eylemlerinden dolayı genellikle kendilerine çıkar sağlayabilirler.

Araştırmacılar, çoğunlukla üç tip zorbalıktan söz etmektedirler: sosyal dışlama, fiziksel ve sözel zorbalık (Olweus, 1993). Son ikisi, gözlenebilirliğinden dolayı doğrudan zorbalık içinde yer alırken, sosyal dışlama ise dolaylı zorbalık olarak tanımlanmaktadır. Dedikodu yaymak, istenileni yapmadığ 1 takdirde arkadaşlığı bitirmekle tehdit etmek gibi doğrudan gözlenmeyen davranışları içeren dolaylı zorbalık, ilişkisel saldırganlık terimiyle de ifade edilmektedir (Crick ve Bigbee, 1998). Bunun yanı sira, zorbalık, hapishane (Ireland ve Ireland, 2003) ya da üniversite iş ortamı gibi (Spratlen, 1995) her kurumda görülebilmesine karşın, çoğunlukla ilk ve ortaöğretim ortamlarında çalışılmaktadır (Craig ve Pepler, 2003; Seals ve Young, 2003). Belki de bunun bir nedeni, zorbalığın gelişimsel olarak bir risk faktörü olduğuna işaret eden çalışmalardır. Bu çalışmalardan birinde, yaşlara göre, zorbalık ve kurbanlık kavramlarının anlaşılmasında/ değerlendirilmesinde bir farklılık olup olmadığı incelenmiştir. Ondört ülkeden 1245 öğrencinin katıldığı bu araştırmada, 8 yaşındakilerin yalnızca saldırgan olan ve olmayan davranışları ayırt edebildikleri görülürken, 14 yaşındakilerin kavga etmeyle bedensel zorbalığ 1 ve sözel zorbalıkla sosyal dışlamayı ayırt edebildikleri görülmektedir (Smith, Cowie, Olafssen ve Liefooghe, 2002). Kimi araştırmalar da yaşla birlikte zorbalığın değil, zorbalığa maruz kalmaya ilişkin bildirim oranının azaldığını belirtmektedirler. Örneğin, Salmivalli (2002), ilköğretim öğrencileriyle yaptığı bir araştırma sonucuna dayanarak 'paranoya zorbalığı' olarak da bilinen ve kişinin yalnızca kendisinin bildirdiği -arkadaşlarının bildirmediğizorbalık oranında yaşa bağlı olarak düşüş olduğunun altını çizmektedir.

Türkiye'de zorbalıkla ilgili araştırmaların sayısı oldukça sınırlıdır. $\mathrm{Bu}$ çalışmalardan birinde, Yıldırım (2001), 8 ve 11 yaş gruplarındaki çocuklarda zorbalık, popülarite ve aile ortamı arasındaki ilişkilere bakmıştır. Çocuklar, a) zorba, b)kurban, c)zorba-kurban ve ç) kontrol grubu olmak üzere dört farklı gruba ayrıldıktan sonra, yetiştirildikleri aile ortamı ve popüler-dışlanan gibi sosyometrik değerlendirmeler açısından karşılaştırılmıştır. Aile ortamları açısından gruplar arasında herhangi bir farklılık bulunmamıştır. İşbirliği yapma, kavga etme, rahatsız etme, liderlik ve çekingenlik gibi davranış özellikleri açısından ise gruplar arasında farklılıklar ortaya çıkmıştır. Zorbalarda, kavga etme ve rahatsız etme özellikleri yüksek bulunurken, kurbanlarda çekingenlik özelliği daha yüksek bulunmuştur. En az sevilenler, zorbalar ve zorba-kurbanlardır. Kurbanlar ve kontrol grubundaki çocuklar -zorba ve zorba/kurbanlara göre- daha fazla sevilen çocuklar olarak değerlendirilmişlerdir.

Başka bir çalışmada ise, zorbalığın ilk ve orta öğretim kurumlarında ne ölçüde ve hangi ortamlarda/mekanlarda görüldügüne ilişkin öğretmen ve yönetici görüşlerine başvurulmuştur (Çınkır ve Karaman-Kepenekçi, 2003). İtme, ad takma, alay etme ve 
cinsellik içeren sözler söyleme en s1k rastlanan zorbalık türleri olarak belirtilmiştir. Ayrıca, zorbalık davranışlarının en çok okul bahçesinde gerçekleştiği ifade edilmiştir.

Temel amacı aile içinde çocuğa yönelik şiddetin görülme sıklığını saptamak olan bir başka çalışmada, ilköğretim 5. ve 8. sınıf öğrencilerine anket aracilığıyla ulaşı1mıştır. $\mathrm{Bu}$ öğrencilere -ne sıklıkta ve kimler tarafindan- fiziksel şiddete maruz kaldıkları sorulmuştur. Öğrencilerin \%74'ü hayatlarında en azından bir kez fiziksel şiddete maruz kaldıklarını bildirmişlerdir. Bu öğrencilerden \%23'ü babalarının, \%20'si arkadaşlarının, \%16's1 annelerinin ve \%14'ü ise öğretmenlerinin kendilerine fiziksel şiddet uyguladıklarını ifade etmişlerdir (Deveci ve Açık, 2002) Görüldüğü gibi, bir arkadaşın diğerine uyguladığı fiziksel şiddetin görülme sıklı̆̆ öğretmen ya da anne tarafindan uygulanan fiziksel şiddetten daha yüksek bulunmuştur.

Espelage ve Swearer (2003), Bronfenbrenner'in ekolojik sistem kuraminın zorbalığı açıklayabilecek bir çerçeve sunduğunu belirtmektedirler. Ekolojik sistem kuramı temele alındığında, zorbalık, kişisel ve kişiler arası değişkenlerin karşı1ıklı etkileşiminin bir ürünüdür. Akran grubu, aile, okul ve diğer toplumsal faktörler gibi ekolojik bağlamlar hem bireysel özellikleri etkilemekte, hem de ondan etkilenmektedir. $\mathrm{Bu}$ bireysel özelliklerden bir bölümü, yaş, cinsiyet ve ırk/etnik köken gibi değişkenlerdir. Bir bölümü de depresyon, kaygı ve benlik saygısı gibi daha çok psiko-sosyal değişkenlerdir.

Zorbalığa maruz kalan çocukların pek çok psikolojik değişken açısından risk grubunda oldukları kabul edilmektedir (Craig ve Pepler, 2003). Zorbalığa maruz kalan çocukların daha fazla psikolojik yardıma gereksinim duydukları, depresyon ve kaygı düzeylerinin daha yüksek olduğu ve benlik saygılarının da daha düşük olduğu bildirilmektedir (Craig, 1998). Zorbalığın çocuklara hem stres, hem de zarar vermesinin yanı sıra, çocuklukta yaşanan zorbalığın olumsuz etkilerinin yetişkin yaşamında da devam edebildiği, zorbalıktan yalnızca kurbanların değil, zorbaların da olumsuz biçimde etkilendiği de belirtilmektedir (Farrington, 1993; akt: Ahmed, ve Braithwaite, 2004).

Yukarıda da belirtildiği gibi, Türkiye'de zorbalıkla ilgili yapılan araştırmalar oldukça sınırlıdır. Hem eğitsel hem de psikolojik açıdan oldukça olumsuz etkileri olabilen zorbalığın ilköğretimdeki genel görünümü hakkında bilgi edinmek oldukça önemli olabilir: İlköğretim öğrencilerinin ne ölçüde ve ne tür zorbalıklara maruz kaldıkları gibi. Zorbalık türü ve yoğunluğunun cinsiyet, sınıf düzeyi ve sosyo-ekonomik düzey gibi demografik değişkenlerle nasıl farklılaştı̆̆ risk faktörü olup olmadığı-, zorbalığa maruz kalmanın benlik saygısı, depresyon ve kaygı düzeyini nasıl etkilediği de bilinmemektedir. Bu soruları yanıtlayabilmek için planlanan bu araştırmanın amaçları aşağıdaki gibi özetlenebilir:

1. İlköğretim 4. ve 5. sınıf öğrencilerinin maruz kaldıkları zorbalık türleri nelerdir ve bunların görülme sıklığı (prevalence) nedir?

2. Zorbalığın türü, sosyo-ekonomik düzey, sınıf düzeyi ve cinsiyete bağlı olarak farklılaşmakta mıdır? 
3. Zorbalığa maruz kalmak a) benlik saygısı, b) depresyon, c) durumluk kaygı ve ç) sürekli kaygı düzeylerinde bir farklılık yaratmakta mıdır?

\section{YÖNTEM}

\section{Katılımcılar}

Ankara'daki 5 devlet ilköğretim okulundan ve 7 sinıftan toplam 206 öğrenci bu araştırmaya katılmıştır. Okulların -bulundukları semtlere göre- alt (n: 111, \%56) ve orta (n: 91, \%44) sosyo-ekonomik düzeyleri temsil ettikleri düşünülmektedir. Katılımcıların 74'ü 4. sınıfa; 132 'si 5. sınıfa devam etmektedirler. Çocukların yaş ortalaması 10.8'dir (SS: .62). Çocukların 99'u kız (\%48.1) ve 107'si (\%51.9) erkektir. Her bir sınıftaki çocuk sayısı 25 ile 44 arasında değişmektedir.

\section{İşlem}

$\mathrm{Bu}$ araştırma, genel tarama modeline dayanmaktadır. Çocuklar sınıflarında, öğretmenlerinin de eşliğinde kendi bildirimlerine dayanan anket ve ölçekleri doldurmuşlardır. Çocuklardan kimlik bilgileri istenmemiştir. Çocuklarla kısa bir sohbetten sonra, kendileri ve okulda yaşadıkları kimi güçlükler hakkında sorular sorulacağı söylenmiştir. Bunun bir sınav ya da test olmadığı, soruların doğru ya da yanlış yanıtları olmadığı özellikle ifade edilmiştir. Ayrıca, verdikleri yanıtların gizliliği konusunda çocuklara güvence verilmiştir. Uygulamanın ardından çocuklara gösterdikleri işbirliğinden dolayı teşekkür edilmiştir. Uygulanan ölçeklerde yanlı yanıtlama olasılığını dengelemek amacıyla, araçların hepsi sıraları değiştirilerek verilmiştir. Ancak durumluk kayg1 ölçeği her zaman sürekli kayg1 ölçeğinden önce verilmiştir. Mart 2004 tarihinde gerçekleştirilen uygulama yaklaşık 40 dakika sürmüştür.

\section{Değerlendirme Araçları}

Çocuklar İçin Durumluk-Sürekli Kaygı Envanteri Spielberger (1973) tarafından geliştirilen bu ölçeklerin geçerlik ve güvenirlik çalışmalarını Özusta, (1995) gerçekleştirmiştir. 9-12 yaş grubu çocuklarında durumluk ve sürekli kaygı düzeyini ölçmek amacıyla kullanılmaktadır. Ölçeğin geçerlik ve güvenirlik çalışmaları ilköğretimin 3, 4, 5 ve 6 . sınıflarına devam eden toplam 724 çocukla yapılmıştır. Bireysel ya da grup olarak uygulanabilmektedir.

1. Sürekli Kaygı Ölçeği: Kaygı yatkınlığının yanı sıra kalıcı bireysel farklılıkları ölçmeyi amaçlar. Ölçek toplam 20 maddeden oluşmaktadır. Çocuğun genellikle nasıl hissettiğini oluş sıklı̆̆na göre değerlendirir. "Evde sinirlerim bozulur" ya da "Ellerim titrer" gibi ifadeler, "hemen hemen hiç", "bazen" ve "sık sık" seçeneklerinden biriyle yanıtlanır. Ölçekten alınacak puanlar 20-60 arasındadır, puanların artışı sürekli kaygıdaki artışı ifade etmektedir.

2. Durumluk Kaygı Ölçeği: Çocuklardan o anda kendilerini nasıl hissettiklerini değerlendirmeleri ve "Kendimi $\square$ çok öfkeli hissediyorum, $\square$ öfkeli hissediyorum, $\square$ öfkeli 
hissetmiyorum" gibi ifadelerden en uygununu işaretlemeleri istenir. Toplam madde sayıs1 20 'dir. Alınabilecek en düşük puan 20, en yüksek puan ise 60'tır.

Durumluk kaygı ölçeği, test koşullarında ortaya çıkabilecek, heyecanlara/ tedirginliklere duyarlı bir ölçek olduğundan uygulamalarda sürekli kaygı ölçeğinden önce verilmesi önerilmektedir.

3. Coopersmith Benlik Saygısı Envanteri 1991 yılında Coopersmith'in geliştirdiği bu ölçek 1996 yılında Pişkin tarafından Türkçe’ye uyarlanmıştır. Öğrencilerin benlik saygısı düzeyini saptamaya yönelik olarak geliştirilen bu ölçeğin hem lise (Pişkin, 1996), hem de ilköğretim 3, 4 ve 5. sınıf öğrencileriyle (Güçray, 1989) kullanılabileceği önerilmektedir. "Sınıfın önünde konuşma yapmak bana oldukça güç gelir" gibi ifadelerin "Evet" ya da "Hayır" biçiminde yanıtlanması beklenmektedir. Ölçek toplam 58 maddeden oluşmaktadır. Bu maddelerin 8'i savunucu tutumlara karşılık gelen yalan maddeleri olarak değerlendirilmekte, 5 ve daha fazla madde savunucu biçimde yanıtlandığında değerlendirmelerden çıkarılması önerilmektedir. Bu araştırmada da 5 ve daha fazla puan alan toplam 13 öğrencinin sonuçları araştırmaya dahil edilmemiştir. Ölçekten alınabilecek puan aralığı 0-50'dir, puan artışı benlik saygısının yüksekliğini ifade etmektedir.

4. Çocuklar İçin Depresyon Ölçeği Çocuklarda depresyon belirtilerinin düzeyini belirlemek amaciyla Kovacks'ın (1985) geliştirdiği bu ölçeğin Türkiye'de 9-14 yaş grubundaki çocuk ve ergenlere uygulanabileceği gösterilmiştir (Öy,1991). Üç seçenekli toplam 27 maddeden oluşan ölçek maddeleri 0,1,2 olarak puanlanmakta ve puan artış1 depresyon belirtilerinin yüksekliğini göstermektedir. Alınabilecek en yüksek puan 54'tür.

5. Şiddet-Kaba güç Anketi Okullarda yaşanan zorbalığın bedensel (itme, tekme atma gibi) sözel, (ad takma, alay etme gibi) duygusal (gruptan dışlama, eşyalarına zarar verme gibi) ve cinsel (elle taciz, cinsellik içeren sözler söyleme gibi) olmak üzere dört ayrı kategoride incelenebileceği önerilmektedir (Elliot, 1997). Çınkır ve Karaman-Kepenekci (2003), önerilen bu siniflandirmalara uygun, toplam 19 maddelik bu anketi geliştirmişlerdir. Anketteki her bir maddenin uygulanma sıklı̆̆ , "Hiç bir zaman, bir kez, ara sıra, çok sık, her gün" olarak değerlendirilmektedir. Bu araştırmada, maddelerin anlaşılırlığını kolaylaştırmak amacıyla, sorular "Alay etme" ya da "Dedikodu yayma" yerine, "Okuldaki çocuk ya da çocuklar seninle alay ediyorlar mı? ya da "Okuldaki çocuk ya da çocuklar senin hakkında dedikodu yayarlar mı?" biçiminde sorulmuştur. Ek bir madde eklenerek, çocuklara, belirtmek istedikleri başka bir örnek durumu yazabilecekleri söylenmiştir.

\section{BULGULAR}

$\mathrm{Bu}$ araştırmanın ilk amacı, ilköğretim 4. ve 5. sınıf öğrencilerinin ne tür zorbalıklara, ne ölçüde maruz kaldıklarını ve dolayısıyla zorbalık türlerinin görülme sıklığını belirlemektir. 'Şiddet-Kabagüç Anketi'nden elde edilen veriler zorbalık türleri ve bunlara maruz kalma sıklığı açısından değerlendirildiğinden, öğrencilerin verdikleri yanıtlar yüzdelik olarak sunulmuştur (Bkz. Tablo I). 
Tablo I'den görüleceği gibi, bedensel zorbalık sınıflandırmasına giren davranışlar içerisinde, "itme" oldukça sik biçimde gözlenmekte, bunu "tekme ya da tokat atma" ve "bedene yapılan kaba şakalar" izlemektedir. Öğrencilerin bir bölümü ise seyrek de olsa "silah, bıçak gibi tehlikeli bir aletle saldırı"ya maruz kalmaktadırlar.

Tablo I. İkögretim 4. ve 5. sinı öğrencilerinin maruz kaldıkları zorbalık türleri ve bunların görülme sıkliğı

\begin{tabular}{|c|c|c|c|c|c|c|}
\hline \multirow[b]{2}{*}{$\begin{array}{c}\text { Zorbalık } \\
\text { Türü }\end{array}$} & \multirow[b]{2}{*}{ Zorbalığın Gösterilme Biçimi } & \multicolumn{5}{|c|}{ Görülme S1klığ1 } \\
\hline & & $\begin{array}{c}\text { Hiç bir } \\
\text { zaman (\%) }\end{array}$ & $\begin{array}{c}\text { Bir kez } \\
(\%)\end{array}$ & Ara sira (\%) & $\begin{array}{c}\text { Çok s1k } \\
(\%)\end{array}$ & $\begin{array}{c}\text { Her gün } \\
(\%)\end{array}$ \\
\hline \multirow{5}{*}{$\begin{array}{l}\bar{D} \\
\tilde{D} \\
\overline{0} \\
\bar{D} \\
\infty\end{array}$} & 1.İtme & $67(32)$ & $25(12)$ & $90(44)$ & $7(3)$ & $14(7)$ \\
\hline & 2.Tekme ya da tokat & $117(57)$ & $36(17)$ & $41(20)$ & $4(2)$ & $2(1)$ \\
\hline & 3.Tehlikeli aletle saldırı & $193(94)$ & $6(3)$ & $1(.05)$ & $3(1.5)$ & 0 \\
\hline & 4. Saç/kulak çekme & $132(64)$ & $25(12)$ & $38(18)$ & $3(1.5)$ & $1(.5)$ \\
\hline & 5. Bedene kaba şaka & $101(49)$ & $33(16)$ & $60(29)$ & $4(2)$ & $5(2.5)$ \\
\hline \multirow{7}{*}{$\begin{array}{l}\overrightarrow{\mathcal{N}} \\
: 0 \\
\text { i }\end{array}$} & 6. Ad takma & $90(44)$ & $53(26)$ & $31(15)$ & $11(5)$ & $12(6)$ \\
\hline & 7. Alay etme & $118(57)$ & $24(12)$ & $42(20)$ & $10(5)$ & $7(3)$ \\
\hline & 8. Takılma & $96(47)$ & $23(11)$ & $66(32)$ & $8(4)$ & $6(3)$ \\
\hline & 9. Laf atma & $143(69)$ & $12(6)$ & $33(16)$ & $11(5)$ & $1(.5)$ \\
\hline & 10. Hakaret küfür & $108(52)$ & $35(17)$ & $41(20)$ & $9(4)$ & $8(4)$ \\
\hline & 11. Tehdit etme & $164(80)$ & $20(10)$ & $12(6)$ & $5(2)$ & $1(.5)$ \\
\hline & 12. Dedikodu yayma & $122(59)$ & $29(14)$ & $36(18)$ & $8(4)$ & $3(2)$ \\
\hline \multirow{4}{*}{$\begin{array}{l}\overline{\widetilde{J}} \\
\tilde{D}_{0} \\
\overrightarrow{0} \\
\overrightarrow{0}\end{array}$} & 13. Gruptan dışlama & $153(74)$ & $21(10)$ & $18(9)$ & $5(2)$ & $4(2)$ \\
\hline & 14. Küçük düşürme & $146(71)$ & $26(13)$ & $20(10)$ & $3(2)$ & $2(1)$ \\
\hline & 15. Ayrımcılık yapma & $123(60)$ & $32(16)$ & $39(19)$ & $3(2)$ & $5(2)$ \\
\hline & 16. Eşyaya zarar verme & $96(47)$ & $43(21)$ & $44(21)$ & $9(4)$ & $6(3)$ \\
\hline \multirow{3}{*}{ 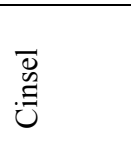 } & 17. Cinsellik içeren sözler & $148(72)$ & $17(8)$ & $20(10)$ & $9(4)$ & $7(3)$ \\
\hline & 18. Sarkıntılık & $158(77)$ & $13(6)$ & $19(9)$ & $7(3)$ & 0 \\
\hline & 19. Elle rahatsiz etme & $140(68)$ & $23(11)$ & $27(13)$ & $6(3)$ & $5(2)$ \\
\hline Diğger & 20. Diğger & $32(16)$ & $8(4)$ & $16(8)$ & $6(3)$ & $23(11)$ \\
\hline
\end{tabular}

Sözel zorbalığın görülme sıklı̆̆ına bakıldığında, çocukların yarısından fazlasına ad takıldığını, bunu takılma ve hakaret/küfürün izlediği görülmektedir. Çocukların yarısına yakın bir bölümü hakkında da dedikodu çıkarıldığı, en seyrek görülen sözel zorbalığın ise tehdit edilme olduğu ortaya çıkmaktadır. Duygusal zorbalıkta, en seyrek görülen davranış gruptan dışlama iken, en sık görülen davranış ise çocuğun bir eşyasına zarar verilmesidir. 
Cinsellik ise en seyrek görülen zorbalık türüdür. Ancak yine de, çocukların \%30 kadarı elle rahatsız edilmeye ve cinsellikle ilgili sözleri dinlemeye maruz kaldıklarını ifade etmişlerdir. Uygulama esnasında da çocukların bir bölümü, sarkıntılık teriminin ne anlama geldiğini sormuşlardır. Bu maddenin düşük olarak işaretlenmesinin bir nedeni de çocukların bu terimi anlamakta güçlük çekmesi olabilir. Tablo I'deki veriler üzerinden genel bir değerlendirme yapıldığında, öğrencilerin yarısına yakın bir bölümünün (\%40) bedensel, sözel, duygusal ya da cinsel zorbalığa maruz kaldıkları görülmektedir.

Sosyo-ekonomik düzey (SED), sınıf düzeyi ve cinsiyet değişkenlerinin zorbalığa maruz kalmayla olan ilişkisi bu çalışmanın ikinci sorusudur. Bu soruya yanıt verebilmek için ki-kare istatistiğine dayalı analizler yapılmıştır. İlk aşamada, akran zorbalığına en az maruz kalan \%27'lik (I. Grup: zorbalığa maruz kalmayanlar) ve en fazla maruz kalan \%27'lik grup (II. Grup: zorbalığa maruz kalanlar) belirlenmiştir. Bu belirleme, Çınkır ve Karaman-Kepenekçi'nin (2003) önerdiği bedensel, sözel, duygusal ve cinsel zorbalık türlerine göre gruplandırılan maddelerden çocukların elde ettikleri puanlar toplanarak elde edilmiştir. Böylece, her bir çocuk bir zorbalık türü puanı elde etmiştir. Puanın az olması zorbalığa az maruz kalmayı, çok olması ise zorbalığa çok maruz kalmayı ifade etmektedir. Yukarıda da yazıldığ 1 gibi, alt \%27'lik I. grup zorbalığa en az maruz kalan ve üst \%27'lik II. grup ise en çok maruz kalan grup olarak sınıflandırılmıştır. Ki-kare istatistiğine dayalı karşılaştırmalar bu iki grup arasında yapılmıştır.

Ki-kare analizleri, sözel, cinsel ya da duygusal zorbalığa maruz kalma açısından alt ve orta SED'den öğrenciler arasında anlamlı bir fark olmadığını, bedensel zorbalığa maruz kalma sıklığı açısından ise anlamlı bir fark olduğunu göstermektedir. Orta SED'den öğrenciler alt SED'den öğrencilere göre daha fazla bedensel zorbalığa maruz kalmaktadırlar. $\chi^{2}(1, \mathrm{n}: 112)=12.93, \mathrm{p}<.05$.

4. ve 5. sınıflara devam eden öğrenciler karşılaştırıldığında, sınıflar arasında zorbalık türlerine göre bir fark olmadığı görülmektedir. Ancak, hem bedensel ve hem de duygusal zorbalıkta, alfanın istatistiksel anlamlılık düzeyi olan .05 'e oldukça yakın olduğu görüldüğünden, 4. sinıfların, bedensel ve duygusal zorbalığa daha fazla maruz kalma eğilimi gösterdikleri söylenebilir; $\chi 2(1, \mathrm{n}: 112)=3.82, \mathrm{p}=.051$.

Cinsiyetin zorbalığa maruz kalmada bir fark yaratıp yaratmadığına bakıldığında, erkek çocukların sözel zorbalığa kızlardan daha fazla maruz kaldıkları görülmektedir, $\chi 2$ $(1, \mathrm{n}: 112)=4.36, \mathrm{p}<.05$. Zorbalığın diğer türlerinde ise cinsiyete göre bir farklılık ortaya çıkmamıştır.

$\mathrm{Bu}$ araştırmanın son sorusu, zorbalığa maruz kalmanın a) benlik saygısı, b) depresyon, c) durumluk kaygı ve ç) sürekli kaygı düzeylerinde bir farklılık yaratıp yaratmadığıdır. Bu soruyu yanıtlamak için, zorbalığa en az maruz kalan grupla (alt \%27), en fazla maruz kalan grup (üst \%27), benlik sayg1s1, depresyon ve kayg1 düzeyleri açısından karşılaştırılmışlardır. 
Bağımsız gruplar için yapılan t-testi, bedensel, sözel, duygusal ve cinsel zorbalığa daha fazla maruz kalan çocukların benlik saygılarının, daha az maruz kalan çocuklardan önemli ölçüde düşük olduğunu göstermektedir (Tablo II).

Tablo II. Zorbalığa maruz kalma türleri ile benlik saygısı puanlarına uygulanan t-testi

\begin{tabular}{lcccc}
\multicolumn{5}{c}{ sonuçları } \\
\hline & $\mathrm{n}$ & $\begin{array}{l}\text { Benlik saygısı } \\
\text { değerleri }\end{array}$ & $\mathrm{X}$ (SS) ve t-testi \\
\hline Bedensel zorbalığa düşük düzeyde maruz kalanlar & 56 & $34.99(7.94)$ & \\
Bedensel zorbalığa yüksek düzeyde maruz kalanlar & 56 & $29.80(7.10)$ & $\mathrm{t}(110)=3.64 \mathrm{P}<.05$ \\
Sözel zorbalığa düşük düzeyde maruz kalanlar & 56 & $34.01(8.41)$ & \\
Sözel zorbalığa yüksek düzeyde maruz kalanlar & 56 & $29.75(6.98)$ & $\mathrm{t}(110)=2.92 \mathrm{P}<.05$ \\
Duygusal zorbalığa düşük düzeyde maruz kalanlar & 56 & $35.27(7.60)$ & \\
Duygusal zorbalığa yüksek düzeyde maruz kalanlar & 56 & $28.86(7.10)$ & $\mathrm{t}(110)=4.61 \mathrm{P}<.05$ \\
Cinsel zorbalığa düşük düzeyde maruz kalanlar & 54 & $35.68(7.65)$ & \\
Cinsel zorbalığa yüksek düzeyde maruz kalanlar & 56 & $29.89(7.20)$ & $\mathrm{t}(108)=4.09 \mathrm{P}<.05$ \\
\hline
\end{tabular}

Zorbalığa maruz kalma ile depresyon belirtilerinin düzeyi arasındaki farka bağımsız gruplar için uygulanan t-testi ile bakılmıştır (Tablo III). Sonuçlar, bedensel, duygusal ve cinsel zorbalığa daha fazla maruz kalan çocukların, daha az maruz kalanlardan anlamlı ölçüde daha yüksek depresyon belirtileri gösterdiğini ortaya koymaktadır. $\mathrm{Bu}$ oran, sözel zorbalıkta da anlamlı olma eğilimi göstermektedir $[\mathrm{t}(109)=1.87 ; \mathrm{p}=.06]$.

Tablo III. Zorbalığa maruz kalma türleri ile depresyon düzeyi puanlarına uygulanan ttesti sonuçları

$\mathrm{n} \quad$ Depresyon belirti düzeyi X (SS) ve ttesti değerleri

\begin{tabular}{llll}
\hline Bedensel zorbalığa düşük düzeyde maruz kalanlar & 55 & $4.62(3.67)$ & \\
Bedensel zorbalığa yüksek düzeyde maruz kalanlar & 55 & $6.45(3.64)$ & $\mathrm{t}(108)=2.63 \mathrm{P}<.05$ \\
Sözel zorbalığa düşük düzeyde maruz kalanlar & 56 & $4.86(3.84)$ & \\
Sözel zorbalığa yüksek düzeyde maruz kalanlar & 55 & $6.18(3.62)$ & $\mathrm{t}(109)=1.87 \mathrm{P}=.06$ \\
Duygusal zorbalığa düşük düzeyde maruz kalanlar & 56 & $4.23(3.52)$ & \\
Duygusal zorbalığa yüksek düzeyde maruz kalanlar & 54 & $6.68(3.67)$ & $\mathrm{t}(108)=3.57 \mathrm{P}<.05$ \\
Cinsel zorbalığa düşük düzeyde maruz kalanlar & 54 & $4.48(3.62)$ & \\
Cinsel zorbalığa yüksek düzeyde maruz kalanlar & 55 & $6.18(3.88)$ & $\mathrm{t}(107)=2.36 \mathrm{P}<.05$ \\
\hline
\end{tabular}


Zorbalığa düşük düzeyde maruz kalan ve yüksek düzeyde maruz kalan çocukların hem durumluk hem de sürekli kaygı puanlarına da, bağımsız gruplar için uygulanan ttestiyle bakılmıştır (Tablo IV).

Bedensel, sözel, duygusal ve cinsel zorbalığa yüksek düzeyde maruz kalan çocukların, düşük düzeyde maruz kalan çocuklarla karşılaştırıldıklarında, hem daha yüksek durumluk, hem de daha yüksek sürekli kayg1 belirtilerini gösterdikleri saptanmıştır.

Tablo IV. Zorbalığa maruz kalma türleri ile durumluk ve sürekli kaygı düzeyi puanlarına uygulanan t-testi sonuçları

\begin{tabular}{|c|c|c|c|}
\hline & $\mathrm{n}$ & \multicolumn{2}{|c|}{ Durumluk kaygı düzeyi $\mathrm{X}$ (SS) ve t-testi değerleri } \\
\hline Bedensel zorbalığa düşük düzeyde maruz kalanlar & 56 & $15.82(4.36)$ & $\mathrm{t}(109)=2.93 \mathrm{P}<.05$ \\
\hline Bedensel zorbalığa yüksek düzeyde maruz kalanlar & 55 & $18.27(4.44)$ & \\
\hline Sözel zorbalığa düşük düzeyde maruz kalanlar & 56 & $16.07(3.88)$ & $\mathrm{t}(110)=2.40 \mathrm{P}<.05$ \\
\hline Sözel zorbalığa yüksek düzeyde maruz kalanlar & 56 & $17.87(4.03)$ & \\
\hline Duygusal zorbalığa düşük düzeyde maruz kalanlar & 56 & $15.26(3.71)$ & $t(109)=3.73 P<.05$ \\
\hline Duygusal zorbalığa yüksek düzeyde maruz kalanlar & 55 & $18.24(4.63)$ & \\
\hline Cinsel zorbalığa düşük düzeyde maruz kalanlar & 54 & $15.35(3.59)$ & $\mathrm{t}(107)=4.11 \mathrm{P}<.05$ \\
\hline \multirow[t]{2}{*}{ Cinsel zorbalığa yüksek düzeyde maruz kalanlar } & 56 & $18.50(4.38)$ & \\
\hline & $\mathrm{n}$ & \multicolumn{2}{|c|}{ Sürekli kaygı düzeyi X (SS) ve t-testi değerleri } \\
\hline Bedensel zorbalığa düşük düzeyde maruz kalanlar & 56 & $32.45(7.10)$ & $\mathrm{t}(110)=3.49 \mathrm{P}<.05$ \\
\hline Bedensel zorbalığa yüksek düzeyde maruz kalanlar & 56 & $37.36(7.59)$ & \\
\hline Sözel zorbalığa düşük düzeyde maruz kalanlar & 56 & $32.05(6.90)$ & $\mathrm{t}(110)=3.51 \mathrm{P}<.05$ \\
\hline Sözel zorbalığa yüksek düzeyde maruz kalanlar & 56 & $36.84(7.53)$ & \\
\hline Duygusal zorbalığa düşük düzeyde maruz kalanlar & 56 & $31.52(6.41)$ & $\mathrm{t}(110)=5.07 \mathrm{P}<.05$ \\
\hline Duygusal zorbalığa yüksek düzeyde maruz kalanlar & 56 & $38.11(7.30)$ & \\
\hline Cinsel zorbalığa düşük düzeyde maruz kalanlar & 54 & $31.5(6.69)$ & $\mathrm{t}(108)=4.30 \mathrm{P}<.05$ \\
\hline Cinsel zorbalığa yüksek düzeyde maruz kalanlar & 56 & $37.5(7.99)$ & \\
\hline
\end{tabular}

$\mathrm{Bu}$ bölümdeki sonuçlar genel olarak değerlendirildiğinde, duygusal zorbalığa maruz kalanların, hem benlik saygisı, hem depresyon ve hem de durumluk kaygı puanları açısından en riskli grup oldukları, cinsel zorbalığa maruz kalanların ise sürekli kaygı açısından en riskli grup oldukları görülmektedir.

\section{TARTIŞMA}

Okulda yaşanan zorbalıklar ve bunların sonuçlarına ilişkin araştırmalar son yılların en çok çalışılan konularından biri olmuştur. $\mathrm{Bu}$ ilginin nedenlerinden biri, zorbalığın kişisel ve sosyal bir sorun olması, bir diğer nedeni ise çocuklar üzerindeki 
uzun süreli olumsuz etkileridir (Schwartz, McFayden-Ketchum, Dodge, Pettit, ve Bates, 1998; Ahmed ve Braithwaite, 2004). Türkiye'de, zorbalık konusunda yapılan çalışmalar oldukça sınırlıdır. Oysa ki, zorbalığa ilişkin risk faktörlerinin bilinmesi ve önleme programlarının bu bilgiler ışığında planlanması oldukça önemlidir.

Bu nedenle, ilköğretim 4. ve 5. sınıflara devam eden çocukların maruz kaldıkları zorbalık türleri, sıklığı ve bunların demografik değișkenlerle ilişkisini saptamak, bu araştırmanın temel amaçlarından biridir. Araştırmanın bir diğer amacı ise, zorbalığa maruz kalmanın depresyon, benlik saygısı, durumluk ve sürekli kaygı gibi ruh sağlığının çeşitli boyutlarında herhangi bir farklılık yaratıp yaratmadığını belirlemektir.

Araştırma sonuçları genel olarak değerlendirildiğinde, ilköğretim 4. ve 5. sınıfa devam eden çocukların \%40'ının bir şekilde zorbalığa maruz kaldıkları görülmüştür. Bu oran diğer ülkelerdeki araştırma bulgularına oldukça yakındır (Ahmed ve Braithwaite, 2004). Bu araştırmada sadece zorbalığa maruz kalan çocuklar belirlendiğinden, bu $\% 40$ 'lık oranın içinde, hem zorba hem kurban olan çocukların da bulunduğu unutulmamalıdır.

Sosyo ekonomik düzey, sınıf düzeyi ve cinsiyet değişkenleri açısından gruplar arasında belirgin farklı1ıklar bulunmamıştır. Yalnızca, orta SED'den gelen çocukların bedensel zorbalığa daha fazla maruz kaldıkları görülmüştür. Bu bulgu, Wolke, Woods, Stanford ve Schulz'un (2001) İngiltere ve Almanya'da yaptıkları karşılaştırmalı bir araştırma bulgusuyla tutarlık göstermektedir. SED’in zorbalıkla oldukça güçsüz bir bağının olduğunu ve her SED'den çocuğun zorbalığa maruz kaldığını belirtmektedirler. Benzer biçimde, kız ve erkek çocuklar arasında da yalnızca sözel zorbalıkta bir fark bulunmuştur; erkek çocuklar k1z çocuklardan daha fazla sözel zorbalığa maruz kaldıklarını bildirmektedirler. Diğer ülkelerde yapılan araştırmalar da genel olarak erkek çocukların kız çocuklardan daha fazla zorbalığa maruz kaldıklarını göstermektedir (Warden ve McKinnon, 2003). İngiliz ve Zambiyalı ilköğretim öğrencilerini karşılaştıran bir başka çalışmada da erkek çocuklar, her tür zorbalığa (bana tekme atar, eşyamı kırar, para ister gibi) kız çocuklardan daha fazla maruz kaldıklarını bildirmektedirler (Nabuzoka, 2003). Ancak burada eklenmesi gereken bir nokta, erkek çocuklarının, aynı zamanda kız çocuklarından daha fazla zorba davranışlar da sergilediğidir (Seals ve Young, 2003).

Diğer ülkelerde yapılan kimi çalışmalar, zorbalığa maruz kalmanın benlik saygısında bir farklılık yaratmadığını göstermektedir. Seals ve Young, (2003), zorba, zorba-kurban ve kurbanların benlik saygısı açısından istatistiksel olarak anlamlı bir farklı1ık göstermediğini, ancak zorbaların en yüksek, kurbanların da en düşük benlik saygısına sahip olduğu yönünde bir eğilimin gözlendiğini belirtmektedirler. $\mathrm{Bu}$ araştırmada ise, zorbalığın türü ne olursa olsun, buna maruz kalmanın benlik saygısını olumsuz yönde etkilediği görülmüştür. Vurgulanması gereken bir başka nokta da, zorbalığa maruz kalma, yalnızca benlik saygısını değil, hem durumluk ve sürekli kaygı ve hem de depresyon belirtilerini etkilemektedir. Her ne kadar sözel zorbalığa maruz kalma 
depresyon puanlarında anlamlı bir farka neden olmasa da, eğilimin bu yönde olduğu izlenmektedir $(\mathrm{p}=.06)$.

Bir başka bulgu da, duygusal zorbalığın, diğer tüm zorbalık türlerinden daha fazla oranda benlik saygısını, depresyonu ve durumluk kaygıyı etkilemesidir. Craig de (1998), zorbalığa maruz kalanların depresyon ve kaygı belirtileri gösterdiklerini ifade etmektedir. Maruz kalınan zorbalık türüne göre kız ve erkek çocukların nasıl başettiklerine ilişkin çalışmalar yapılmakla birlikte (Kristensen ve Smith, 2003), yine maruz kalınan zorbalık türünün depresyon, benlik saygısı ve kaygı düzeyini nasıl etkilediğine ilişkin bir yayına rastlanmamıştır. $\mathrm{Bu}$ araştırma, her tür zorbalığın ruh sağlığını olumsuz yönde etkilediğini ve duygusal zorbalığa maruz kalmanın ruh sağlığı açısından en önemli bir risk faktörü olduğunu göstermektedir.

\section{ÖNERILLER}

Zorbalık kişisel, sosyal ve eğitsel bir sorundur. Zorbalığın kısa ve uzun dönem etkilerini ve zorbalığa neden olan -olası- risk faktörlerini belirlemek ve bu bulgular 1şı̆̆ında önleme çalışmalarını planlamak çocuklar, aileler ve eğitimciler adına en önemli araştırma alanlarından biri olarak görünmektedir. Bu çalışmaların yürütülmesinde, en önemli grup, çocuklar, aileler ve öğretmenlerdir. Bunlardan herhangi birinin göz ard1 edilmesi, oldukça önemli olabilecek bilgi kayıplarına neden olabilir. Örneğin, Yoon ve Kerber (2003), yaptıkları bir araştırmada öğretmenlerin zorbalıkla mücadele ettiklerini belirttiklerini ve öğrencilerinin ise (öğretmenlerinin) mücadele etmediklerini belirttiklerini ortaya koymuştur. Ayrıca, öğretmenlerin de kimi zaman bir disiplin yöntemi olarak şiddete başvurduklarını belirtmektedir.

Çocuk, ailesi ve öğretmenle ilgili değişkenlere ilişkin araştırmalar yürütülürken, aynı zamanda bu konuda bilgilendirme ve zorbalığı önleme çalışmalarının da yapılması, öncelikle çocuk adına oldukça önemlidir ve eğitimcileri bekleyen temel çalışma alanı olarak alan yazında yerini almıştır.

\section{KAYNAKLAR}

Ahmed, E., Braithwaite, V. (2004). Bullying And Victimization: Cause For Concern For Both Families And Schools. Social Psychology of Education, 7, 35-54.

Coopersmith, S. (1991). The SEI-Self Esteem Inventories. Palo Alto: Consulting Psychologist Press.

Craig, W. M. (1998). The Relationship Among Bullying, Victimization, Depression, Anxiety And Aggression In Elementary School Children. Personality And Individual Differences, 24, 123-130.

Craig, W. M., Pepler, D. J. (2003). Identifying And Targeting Risk For İnvolvement İn Bullying And Victimization. The Canadian Journal Of Psychiatry, 48, 577-582. 
Crick, N. R., Bigbee, M. A. (1998). Relational And Overt Forms Of Peer Victimization: A Multi Informant Approach. Journal Of Consulting And Clinical Psychology, 66, 337347.

Çınkır, Ş., Karaman-Kepenekci, Y. (2003). Öğrenciler Arası Zorbalık. Kuram Ve Uygulamada Ĕ̈itim Yönetimi, 34, 236-253.

Deveci, S. E. , Açık, Y. (2002). İlköğretim Öğrencilerinin Fiziksel Şiddete Maruziyetleri ve Yaklaşımları. Retrieved from http://www.dicle.edu.tr/ halks/m9.29.htm

Elliot, M. (1997). 101 Ways Of Dealing With Bullying. London: Hodder Children's Book.

Espelage, D.L., Swearer, S. M. (2003). Research on School Bullying and Victimization: What Have We Learned and Where Do We Go From Here? School Psychology Review, 32, 365-383.

Farrington, D. P. (1993). Understanding and Preventing Bullying. İçinde: M. Tonry ve N. Morris (Ed). Crime and Justice (Vol.17). Chicago: University of Chicago Press.

Güçray, S. (1989). Çocuk Yuvasinda ve Ailesi Yanında Kalan 9-10 Ve 11 Yaş Çocukların Özsaygı Gelişimini Etkileyen Bazı Faktörler. Yayınlanmamış Doktora Tezi. Ankara: Hacettepe Üniversitesisosyal Bilimler Enstitüsü.

Ireland, J. L., Ireland, C. A. (2003). How Do Offenders Define Bullying? A Study Of Adult, Young And Juvenile Male Offenders. Legal And Criminological Psychology, $8,159-173$.

Kovacks, M. (1985). The Children's Depression İnventory. Psychopharmacology Bulletin, 21, 995-998.

Kristensen, S. M., Smith, P. K. (2003). The Use Of Coping Strategies By Danish Children Classed As Bullies, Victims And Bully/Victims And Not Involved in Response to Different Types of Bullying. Scandinavian Journal of Psychology, 44, 479-488.

Nabuzoka, D. (2003). Experiences Of Bullying-Related Behaviours By English And Zambian Pupils: A Comparative Study. Educational Research, 45, 95-104.

Neary, A., Joseph, S. (1994). Peer Victimisation And İts Relationship To Self Concept And Depression Among Schoolgirls. Personality and Individual Differences, 16, 183-186.

Olweus, D. (1993). Bullying At School: What We Know and What We Can Do. Oxford: Blackwell.

Öy, B. (1991). Çocuklar İçin Depresyon Ölçeği: Geçerlik ve Güvenirlik Çalışması. Türk Psikiyatri Dergisi, 2, 132-136.

Özusta, H. Ş. (1995). Çocuklar İçin Durumluk-Sürekli Kayg1 Envanteri Uyarlama, Geçerlik Ve Güvenirlik Çalışması. Türk Psikoloji Dergisi, 10, 32-44.

Pişkin, M. (2002). Okul Zorbalığı: Tanımı, Türleri, İlişkili Olduğu Faktörler Ve Alınabilecek Önlemler. Kuram Ve Uygulamada Eğitim Bilimleri Dergisi, 2, 531-562.

Salmivalli, C. (2002). Is there an Age Decline in Victimization by Peers at School? Educational Research, 44, 269-278.

Schafer, M., Werner, N. E., Crick, N. R. (2002). A Comparison of Two Approaches To The Study Of Negative Peer Treatment: General Victimization And Bully/Victim 
Problems Among German Schoolchildren. British Journal of Developmental Psychology, 20, 281-306.

Schwartz, D., Mcfayden-Ketchum, S. A. Dodge, K. A., Pettit, G. P., Bates, J. E. (1998). Peer Victimization As A Predictor Of Behavior Problems At Home And İ School. Development and Psychopathology, 10, 87-100.

Seals, D., Young, J (2003). Bullying And Victimization: Prevalence And Relationship To Gender, Grade Level, Ethnicity, Self-Esteem, and Depression. Adolescence, 38, 735747.

Smith, P. K., Cowie, H., Olafssen, R. F., Liefooghe (2002). Definitions of Bullying: A Comparison of Terms Used and Age and Gender Differences in a Fourteen-Country International Comparison. Child Development, 73, 1119-1133.

Spielberger, C. D. (1973). Manual For The State-Trait Anxiety Inventory For Children. Palo Alto: Consulting Psychologist Press.

Spratlen, L. P. (1995). Interpersonal Conflict Which İncludes Mistreatment İn A University Workplace. Violence and Victims, 10, 285-297.

Warden, D., Mackinnon, S. (2003). Prosocial Children, Bullies And Victims: An İnvestigation Of Their Sociometric Status, Empathy And Social Problem Solving Strategies. British Journal of Developmental Psychology, 21, 367-385.

Wolke, D., Woods, S., Stanford, K. Ve Schulz, H. (2001). Bullyıng And Victimization of Primary School Children In England and Germany: Prevalence And School Factors. British Journal of Psychology, 92, 673-696.

Yıldırım, S. (2001). The Relationships of Bullying, Family Environment and Popularity. Yayınlanmamış Yüksek Lisans Tezi. Orta Doğu Teknik Üniversitesi.

Yıldırım, S. (2001). Zorbalık, Aile Ortamı ve Popülarite Arasındaki Iliş̧kiler. Yayınlanmamış Yüksek Lisans Tezi. Orta Doğu Teknik Üniversitesi. Sosyal Bilimler Enstitüsü. Ankara.

Yoon, J. S., Kerber, K. (2003). Bullying. Research in Education, 69, 27-35. 